\title{
SOIL-BORNE FUNGI UNLIKELY PRIMARY CAUSE OF WILT IN BORONIA MEGASTIGMA OIL CROPS
}

\author{
R.E. FALLOON ${ }^{1}$, P.G. BROADHURST ${ }^{2}$ and H.M. NOTT ${ }^{1}$ \\ ${ }^{I}$ New Zealand Institute for Crop \& Food Research Ltd.,Private Bag 4704, Christchurch and \\ ${ }^{2}$ Mt Albert Research Centre, Private Bag 92169, Auckland
}

\begin{abstract}
Wilting and death of Boronia megastigma Nees cx Bartling plants is common in oil crops and can severely harm productivity. Several fungicide soil treatments likely to control particular groups of plant pathogens were tested for wilt prevention in two field trials in crops near Mapua and Upper Moutere, Nelson. Metalaxyl granules (active against Phytophthora and Pythium spp.), or drenches of prochloraz, benomyl (both with broad activity, including against Fusarium spp. and Chalara elegans Nag Raj \& Kendrick), or metalaxyl + prochloraz were applied to soil around trunk bases of individual plants on seven occasions at 4-month intervals. No differences in plant survival were detected between treated plants and those drenched with equivalent rates of water, or amongst any of the fungicide treatments. Plant survival over 2 years was least $(35 \%)$ on a sandy site prone to flooding and greatest $(60 \%)$ on a hill site. At the sandy site, survival oftwo clones was markedly different (67and $4 \%$ respectively). No single fungus was consistently isolated from roots or trunks of wilting, field-grown plants. In glasshouse pathogenicity tests, no differences $(\mathrm{P}>0.05)$ in plant survival were detected between uninoculated B. megastigma plants (90\% survival 10 weeks later) or inoculated plants ( $80-100 \%$ survival) exposed to representative isolates of 10 potentially pathogenic fungi obtained from wilting, field-grown plants. Results suggest that factors other than soil-borne fungi (e.g. water-logged or otherwise unfavourable soils, other pathogen types) are the primary cause(s) of boronia wilt.
\end{abstract}

\section{STORAGE ROTS OF CARROT AND THEIR CONTROL}

\author{
L.H. CHEAH, D.W. BRASH and A.P. MARSHALL
}

N.Z. Institute for Crop \& Food Research Ltd, Private Bag 4005, Levin, N.Z.

Fresh carrots have become one of the promising new export crops from New Zealand to Asia. Export value has risen from NZ\$1 million in 1993 to about NZ\$4.3 million in 1995. Postharvest storage rot caused by various pathogens has become a widespread problem and identified as a top priority research area by the Research Committee of the Fresh Sector of the New Zealand Vegetable and Potato Growers Federation. In 1995, a monitoring trial was carried out to check cool-stored (0-I TC) carrots for quality and storage rot at monthly intervals up to three months. Disease diagnosis was carried out to identify the micro-organisms associated with the rots and to test their pathogenicity on carrots. Seven fungi (Cladosporium sp., Fusarium sp., Penicillium sp., Pythium sp., Rhizopus sp., Sclerotinia sclerotiorum and Thielaviopus basicola) and one bacterial species (Erwinia carotovora) were isolated. S. sclerotiorum and T. basicola were found to be highly pathogenic. This is the first record of T. basicola on cool-stored carrots in New Zealand. The remaining organisms were either cosmetic or weak pathogens. Seven fungicides were tested for control of these two pathogens on carrots. Benomyl, iprodione and vinclozolin $(0.5 \mathrm{~g} / \mathrm{l})$ were found to be highly effective. Appropriate postharvest cool storage treatments are important. Delays in cooling after harvest increased the incidence of rots in storage. 